\title{
Albinism in Carollia perspicillata (Chiroptera; Phyllostomidae), in the state of Rondônia, Brazil. A brief review of albinism in bats
}

\author{
Adriana Ruckert da Rosa 1 * \\ Luzia Fátima Alves Martorelli ${ }^{1}$ \\ Marilene Fernandes de Almeida ${ }^{1}$ \\ Caroline Cotrin Aires ${ }^{2,3}$ \\ ${ }^{1}$ Centro de Controle de Zoonoses, Coordenação de Vigilância em Saúde \\ Prefeitura da Cidade de São Paulo \\ Rua Santa Eulália, 86, Santana, CEP 02031-020, São Paulo - SP, Brazil \\ ${ }^{2}$ Supervisão de Vigilância em Saúde, Secretaria Municipal de Saúde \\ Prefeitura da Cidade de São Paulo, São Paulo - SP, Brazil \\ ${ }^{3}$ Universidade Mogi das Cruzes, Mogidas Cruzes - SP, Brasil \\ * Corresponding author \\ arosa@prefeitura.sp.gov.br
}

Submetido em 19/09/2016

Aceito para publicação em 02/05/2017

\section{Resumo}

Albinismo em Carollia perspicillata (Chiroptera; Phyllostomidae), no Estado de Rondônia, Brasil. Uma breve revisão de albinismo em morcegos. Albinismo é um fenômeno pouco comum em morcegos. Na literatura, 67 espécies de morcegos foram reportadas com a mutação. A proposta desse artigo é relatar um caso de albinismo completo em Carollia perspicillata. Um morcego, jovem, macho, albino foi capturado em um bueiro sob a rodovia BR364, localizado em uma área antropogênica na Vila de Caiçara, município de Porto Velho, no estado de Rondônia. O animal estava aparentemente bem integrado ao grupo, saudável e de tamanho normal para a espécie. Um breve resumo de albinismo em morcegos é apresentado.

Palavras-chaves: Abrigo urbano; Hipopigmentação; Mamíferos

\section{Abstract}

Albinism is a phenomenon that is not very common in bats. In the literature, sixty-seven bat species with this mutation have been reported. The purpose of this paper is to report a case of complete albinism in Carollia perspicillata. A young male albino bat was captured in a culvert under the BR 364 highway, located within an anthropogenic area in the district of Caiçara, municipality of Porto Velho, in the northern Brazilian state of Rondônia. The animal was apparently well integrated into the group, healthy and of normal size for the species. A brief review of albinism in bats is also provided.

Key words: Hypopigmentation; Mammals; Urban shelter 


\section{Introduction}

Albinism is caused by a rare gene mutation that provides instructions for the synthesis of proteins involved in melanin production. Melanin is produced by melanocyte cells, which are found in the skin and eyes. Animals with albinism show a significant reduction in the amount of melanin (partial albinism) or no pigment in the eyes, skin, or hair (true or complete albinism) (NOAH, 2015). In addition, the red eyes of albino animals are caused by the reflection of red blood cells in the retinal blood vessels (MILLER, 2005).

Another pigmentation variation in mammals is leucism, which is characterized by individuals with partial or total discoloration of the skin and/or fur. However, the pigmentation of eyes and claws is normal. Leucism has on occasion been confused with partial albinism and results from a reduction in all types of pigment, while albinism results from only a reduction in melanin production (MILLER, 2005).

Worldwide, complete albinism in bats has been recorded in 64 individuals of 38 species (UIEDA, 2000). Most of the recent cases were published in Latin American and Asian countries.

The neotropical bat genus Carollia (GRAY, 1838) currently includes eight species, five of which are known from Brazil. This genus includes some of the most abundant species of mammals and plays an important role in seed dispersal and regeneration of forests. There are three reports of albinism in $C$. perpicillata (CHARLES-DOMINIQUE et al., 2001; BOADA; TIRIRA, 2010; FALCÃO, 2014). The purpose of this paper is to report a case of complete albinism in Carollia perspicillata (LINNAEUS, 1758), from the Brazilian state of Rondônia, and to provide a brief review of albinism in bats.

\section{Materials and Methods}

The review was developed based on a database search of international (PubMed, ScienceDirect and LILACS) and national (SciELO) literature and annals of the most important events related to Chiroptera, between 2001 and 2015, using the following key words: bats,
Chiroptera, albinism and hypopigmentation. This period was selected because the last list of rabies positive bats for Brazil by UIEDA et al. was published in 2000 .

The record of albinism was made during a fiveyear survey conducted between 2010 and 2014 in three districts (Caiçara, Abunã and Mutum) of the municipality of Porto Velho, in the northern Brazilian state of Rondônia. Daytime collections were performed twice a year, in the dry and rainy seasons. Collections were made in August 2010, March 2011, April and July 2012, February and August 2013, and January and July 2014.

In all three surveyed districts, culverts under the BR364 highway were used as shelters by $C$. perspicillata colonies. The culvert where the albino specimen was found (UTM 0315841 8963087) is in the Caiçara District, is made of iron and has an internal diameter of 2 $\mathrm{m}$ for its entire $20 \mathrm{~m}$ length. It has a double opening and was built in the 1980s (Figure 1). Selected individuals roosting in this culvert were tagged with metal rings and their sex, age and reproductive condition were recorded.
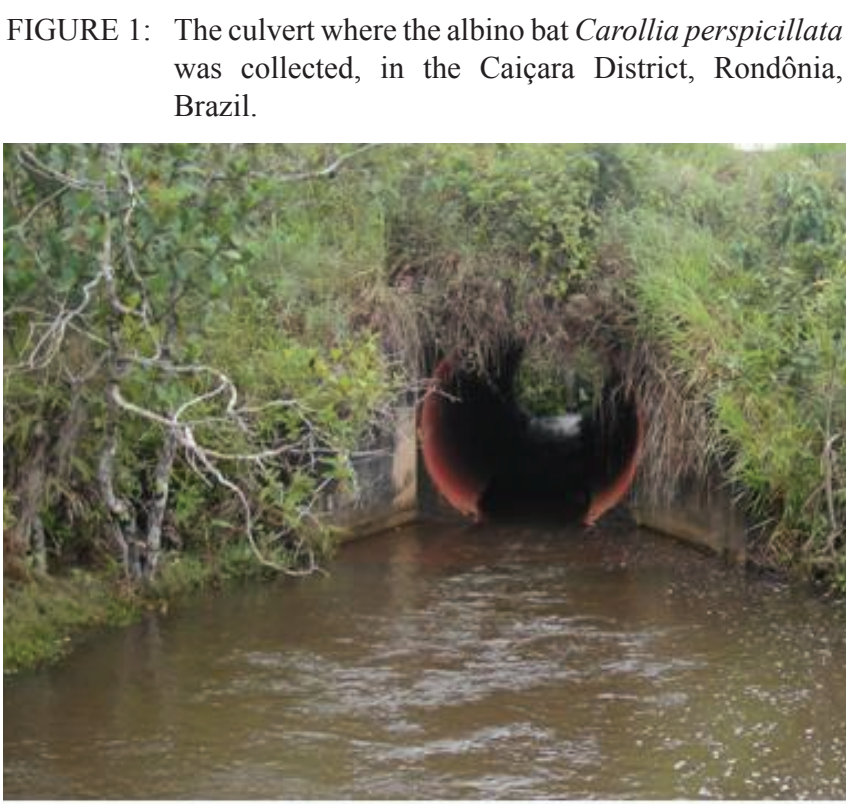

The environment around the shelter includes a perennial lake originating from the enlargement of the stream on both sides of the shelter, in an Amazon rainforest remnant within an anthropic area. The immediate area contains abundant Piperaceae plants, which constitute the main food source for this species (MIKICK et al., 2003). 
The region is categorized as a rainy tropical climate. The average annual temperature ranges from $24^{\circ} \mathrm{C}$ to $26^{\circ} \mathrm{C}$, with little variation throughout the year (only $10^{\circ} \mathrm{C}$ ). The summer is hot and rainy, while the winters are dry and mild. The annual precipitation ranges from 1400 to $2600 \mathrm{~mm}$ (INMET, 2017).

\section{Results}

Table 1 lists the cases of albinism (complete or partial) recorded for bats worldwide since the review by Uieda (2000), totaling sixty-seven species (151 individuals) from 40 countries.

TABLE 1: Records of albinism (complete or partial) in bats according country of collection.

\begin{tabular}{|c|c|c|}
\hline Country & Species & References \\
\hline & 38 species/64 specimens & Uieda (2000) \\
\hline \multirow{3}{*}{ Mexico } & Desmodus rotundus (4), Artibeus jamaicensis (1) & Sánches-Hernández et al. (2010) ** \\
\hline & Artibeus jamaicensis (1), Dermanura watsoni (1), Carollia sowelli (1) & Hernández-Mijangos (2009)* \\
\hline & Glossophaga soricina (1) & García-Morales et al. (2010) \\
\hline \multirow{4}{*}{ Brazil } & Eumops glaucinus (1), Dermanura cinerea $(1)$ & Sodré et al. (2004); Oliveira and Aguiar (2008) \\
\hline & Nyctinomops laticaudatus (4) & Geiger and Pacheco (2006)* \\
\hline & Myotis levis (2) & Miranda et al. (2012) \\
\hline & Carollia perspicillata (2) & Falcão (2014); Present study \\
\hline Canada & Myotis luvifugus (1) & Sodré et al. (2004) \\
\hline \multirow{4}{*}{ Argentina } & Sturnira erythromos (2) & Barquez et al. (2003) * \\
\hline & Eptesicus furinalis (1) & Pautasso et al. (2009) \\
\hline & Desmodus rotundus (1) & Ramírez et al. (2010) \\
\hline & Tadarida brasiliensis (1) & Romano et al. (2015) \\
\hline French Guiana & Rhinophylla pumilio (1), Carollia perspicillata (1) & Charles-Dominique et al. (2001) \\
\hline \multirow{3}{*}{ Venezuela } & Molossus molossus (1), Carollia brevicauda (1) & Soriano et al. (1993)* \\
\hline & Micronycteris microtis (4) & Acosta et al. (2011) \\
\hline & Molossus rufus (1) & Rengifo et al. (2014) \\
\hline $\begin{array}{l}\text { Peru } \\
\end{array}$ & Molossus molossus (1) & Tello et al. (2014)** \\
\hline Ecuador & Carollia perspicillata (1) & Boada and Tirira (2010) ** \\
\hline Colombia & Uroderma bilobatum (3) & Mantilla-Meluk enad Jiménez-Ortega (2011) * \\
\hline Costa Rica & Micronycteris minuta (1) & Gamba-Rios (2010) \\
\hline Spain & Pipistrellus pygmaeus (1) & Alcalde (2009) \\
\hline Czech Republic & Nyctalus noctula (1), Myotis myotis (1) & Murariu and Chisamera (2006); Leblanc and Taupin (2005) \\
\hline Poland & Myotis nattereri (1), Eptesicus serotinus (1) & Leblanc and Taupin (2005) \\
\hline \multirow{2}{*}{ France } & Rhinolophus ferrumequinum (4), Rhinolophus hipposideros (3) & Leblanc and Taupin (2005) \\
\hline & Myotis myotis (2), Myotis emarginatus (1), Miniopterus schreibersi (2) & Prévost et al. (2011) \\
\hline \multirow{2}{*}{$\begin{array}{l}\text { The } \\
\text { Netherlands }\end{array}$} & Plecotus auritus (1), Myotis daubentonii (1), M. dasycneme (1), M. mystacinus (1) & Buys et al. (2002) \\
\hline & Eptesicus serotinus (1) & Natuurbericht (2015) \\
\hline Germany & Pipistrellus pipistrellus (1), Eptesicus serotinus (1), Myotis myotis (1) & Leblanc and Taupin (2005) \\
\hline Croatia & Nytalus noctula $(1)$ & Murariu and Chisamera (2006) \\
\hline Romania & Nytalus noctula $(1)$ & Murariu and Chisamera (2006) \\
\hline $\begin{array}{l}\text { European } \\
\text { Russia }\end{array}$ & $\begin{array}{c}\text { Eptesicus serotinus turcomanus (1), Pipistrellus nathusii (1), } \\
\text { Myotis mystacinus (1) }\end{array}$ & Smirnov et al. (2014) ** \\
\hline Great Britain & Myotis nattereri (1) & Leblanc and Taupin (2005) \\
\hline Switzerland & Eptesicus furinalis (1) & Leblanc and Taupin (2005) \\
\hline Indian & Hipposideros diadema nicobarensis (1), Rhinopoma microphyllum (1) & Devkar et al. (2011); Aul and Marimuthu (2006) \\
\hline Réunion & Mormopterus francoismoutoi (1) Rhinolophus cornutus (1) & Ramasindrazana et al. (2014) \\
\hline Moldova & Eptesicus serotinus (1) & Obada and Gas (2003, apud Smirnov et al., 2014) \\
\hline China & Miniopterus magnate (1) & Feng et al. (2007) \\
\hline Taiwan & Pipistrellus abramus (1), Hipposideros terasensis (1) & Hsu (2003, apud Smirnov et al. 2014) \\
\hline Borneo & Hipposideros cervinus (1) & Naharuddin et al. (2015) \\
\hline Sudan & Scotophilus leucaster (1) & Leblanc and Taupin (2005) \\
\hline Australia & Taphozous georgianus & Leblanc and Taupin (2005) \\
\hline Total & 67 species/151 specimens & \\
\hline
\end{tabular}

* According Marin-Vasques et al. (2010), some of these reports represent cases of leucism. ** These authors used leucism as a synonym for partial albinism. 
When making the eight collections in this shelter where the albino bat (Figure 2) was found, the population of $C$. perpicillata varied from 50 and 200 individuals. While collecting in August 2011 and July 2014, cohabitation of $C$. perspicillata with a few (5 to 10) specimens of Glossophaga soricina (Pallas's long tongued bat) and 10 to 50 specimens of Trachops cirrhosus (fringe-lipped bat) was recorded.

FIGURE 2: Albino specimen of Carollia perspicillata showing the presence of translucent dactylopatagium and red eyes (Photograph by Patrício Rocha).

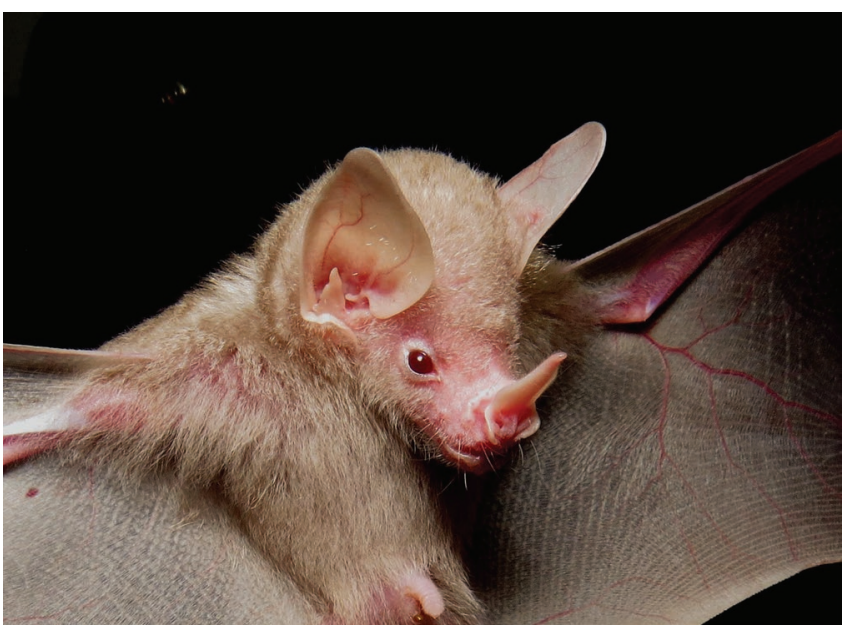

The collected albino individual of $C$. perspicillata (Zoology Museum of the University of São Paulo, Brazil-MZUSP35367) was a young male (right forearm $40 \mathrm{~mm}$; left forearm $39.5 \mathrm{~mm}$; weight $10 \mathrm{~g}$ ). It was roosting in a colony of approximately one hundred normally pigmented $C$. perspicillata. Of these, 39 were females ( 9 were pregnant, 14 were young, 6 were lactating and had their 10 pups with them) and 12 were males ( 8 adults and 4 young).

\section{Discussion}

The albino C. perspicillata reported in this study was roosting in a culvert. According to a review of albino bats published by Uieda (2000), only six of 64 bats were captured with mist nets while flying, and 39 were captured in daytime roosts, such as caves, mines, galleries, buildings, tree holes and bird boxes. The author proposed that these enclosed roosts may be important for the survival of albino bats because they offer protection against sunlight, water loss and predation; this could explain why there are no records of albinism from bat species that preferentially use external roosts. Of the albino specimens reported since the review by Uieda (2000), the majority have been found in enclosed roosts (35 individuals) and just eleven were captured with mist nets or a harp trap (Table 2).

In the review of Uieda (2000) a similar proportion between males (47.4\%) and females (52.6\%) was observed. Among the reports with information about sex since that review, 27 were females $(61.4 \%)$ and 17 were males (38.6\%) (Table 2). In some species, females live in maternity colonies segregated from the males. This fact suggests that females are more easily captured in relation to males, who live in small groups or in various shelters and locations or are segregated from the colony by dominant males, and could explain the predominance of females over males. Romano et al. (2015) reported an albino individual of Tadarida brasiliensis in an attic inhabited by females during the final stages of pregnancy, parturition, and lactation.

The bat subject of this paper was apparently well integrated into the group, healthy and of normal size for the species. Although albinism may bring disadvantages (UIEDA, 2000), some authors have reported that albino bats live long lives (UIEDA, 2000; PRÉVOST et al., 2011). Among 45 bats where the age was reported, 18 $(40 \%)$ were classified as adults. This indicates that albino bats can live until an adult age and become integrated into their colonies.

In relation to reproduction of albino bats, SánchesHernández et al. (2010) found two reproductively active adult females of $D$. rotundus and one pregnant $A$. jamaicensis. Acosta et al. (2011) reported two females, one pregnant and one lactant, of Micronycteris microtis. Miranda et al. (2012) reported two lactant females of Myotis levis. However, an albino female maintained in captivity by Uieda (2001) for 28 months with normally colored males and females did not become pregnant, unlike other females in the group.Based on the review, the majority of the 151 albino individuals, in 27 species, were from the family Vespertilionidae (40.9\%). This was also observed by Uieda (2000), probably because of the high species diversity in the family. 
TABLE 2: Data of records of albino bats according type of shelter and capture, sex and type of albinism.

\begin{tabular}{|c|c|c|c|c|c|c|c|}
\hline \multirow{2}{*}{ Species } & \multicolumn{2}{|c|}{ Shelter } & \multirow{2}{*}{$\begin{array}{l}\text { Mist net/ } \\
\text { Harp trap }\end{array}$} & \multicolumn{2}{|c|}{ Sex } & \multicolumn{2}{|c|}{ Albinism } \\
\hline & Artificial & Natural & & Male & Female & Complete & Partial \\
\hline Artibeus jamaicensis (1) & & & 1 & & & & \\
\hline Carollia perspicillata (3) & 1 & & 2 & 1 & 2 & 2 & 1 \\
\hline Carollia brevicauda $(1) *$ & & & & & 1 & & \\
\hline Dermanura cinerea (1) & & & 1 & 1 & & 1 & \\
\hline Desmodus rotundus (5) * & & 4 & & 3 & 1 & 5 & \\
\hline Eptesicus furinalis (1) & 1 & & & & 1 & 1 & \\
\hline Eptesicus serotinus (1) & & 1 & & 1 & 1 & 2 & \\
\hline Eptesicus serotinus turcomanus (4) & 4 & & & 1 & 3 & & 4 \\
\hline Eumops glaucinus (1) & & & & 1 & & 1 & \\
\hline Glossophaga soricina $(1)$ & & & 1 & & 1 & 1 & \\
\hline Hipposideros cervinus (1) & & & 1 & & 1 & & 1 \\
\hline Hipposideros diadema nicobarensis (1) & & 1 & & 1 & & 1 & \\
\hline Micronycteris microtis (4) & & 4 & & 1 & 3 & & 4 \\
\hline Micronycteris minuta (1) & & & 1 & & 1 & 1 & \\
\hline Miniopterus magnater (1) & & & & & 1 & 1 & \\
\hline Miniopterus schereibersii (1) & & 1 & & & & & \\
\hline Molossus molossus (2) & & & & 1 & 1 & 2 & \\
\hline Molossus rufus (1) & 1 & & & 1 & & 1 & \\
\hline Mormopterus francoismoutoui (1) & & 1 & & & 1 & 1 & \\
\hline Myotis levis (2) & 2 & & & & 2 & & 2 \\
\hline Myotis mystacinus (1) & 1 & & & & 1 & & 1 \\
\hline Nyctalus noctula (3) & 3 & & & & 3 & & 3 \\
\hline Nyctinomops laticaudatus (4) & 4 & & & 2 & 2 & & 4 \\
\hline Pipistrellus nathusii (1) & 1 & & & & 1 & & 1 \\
\hline Pipistrellus pygmaeus (1) & 1 & & & & 1 & 1 & \\
\hline Plecotus auritus (1)* & 1 & & & & & 1 & \\
\hline Rhinolophus ferrumequinum (1) & & 1 & & & 1 & 1 & \\
\hline Rhinopoma microphyllum (1) * & 1 & & & & & 1 & \\
\hline Sturnira erythromos $(2) *$ & & & 1 & 2 & & & 2 \\
\hline Tadarida brasiliensis (1) & 1 & & & & 1 & 1 & \\
\hline Uroderma bilobatum (3) & & & 3 & 1 & 2 & & 3 \\
\hline Total & 22 & 13 & 11 & 17 & 32 & 25 & 26 \\
\hline
\end{tabular}

* incomplete data.

The number of cases of albinism in $D$. rotundus is greater than in other species, and includes 12 individuals, considering all records since UIEDA (2000). However, it is unlikely that this represents a higher incidence of albinism in the species, and probably reflects the high sampling rates of a species targeted by a rabies control program.

Within the subfamily Carolliinae, there have been reports of albinism in Rhinophylla pumilio (CHARLES-DOMINIQUE et al., 2001), Carollia brevicauda (Soriano et al, 1993) and Carollia sowelli (HERNÁNDEZ-MIJANGOS, 2009). Among the three reported cases of albinism in $C$. perspicillata, two were cases of complete albinism (FALCÃO, 2014): an adult female, captured in a mist net; and a young male, captured in a shelter of this study. Boada and Tirira (2010) used leucism as a synonym for partial albinism for an adult female captured by a mist net.

This work reports the second record of albinism for C. perspicillata in Brazil. Given that albinism is a rare 
hypopigmentary disorder, cases should be reported to increase the knowledge of such variation in bats.

\section{Acknowledgments}

We are grateful to Arcadis Logos S/A and the curator of the mammal collection of Museu de Zoologia da Universidade de São Paulo, Dr. Mario de Vivo. License number 190/2012 DILIC/IBAMA.

\section{References}

ACOSTA, L. H.; SÁLDIAS, M.; NÚÑEZ, L. A. Historia natural del murciélago de orejas largas (Micronycteris microtis, Miller 1898) en la serrania de Incahuasi, Santa Cruz - Bolívia. Kempffiana, Zurich, v. 7, n. 2, p. 19-33, 2011.

ALCALDE, J. T. Myotis alcathoe Helversen \& Heller, 2001 and Pipistrellus pygmaeus (Leach, 1825), New Species of Chiroptera in Navarre. Munibe Ciencias Naturales-Natur Zientziak, La Rioja, v. 57, p. 225-236, 2009.

AUL, B.; MARIMUTHU, G. Sighting of an albino bat in a colony of cave-dwelling microchiropteran, Hipposideros diadema nicobarensis at the Nicobar Islands. Current Science, Bangalore, v. 90, n. 7, p. 912-914, 2006.

BARQUEZ, R.; CARRIZO, L.; FERRO, L.; FLORES, D.; MOLLERACH, M.; SÁNCHEZ, M.; GARCÍA-LÓPEZ, A. Primer caso de albinismo total para Sturnira erythromos (Tschudi, 1844) (Chiroptera: Phyllostomidae). Chiroptera Neotropical, Brasília, v. 9, n. 1-2, p. 166-169, 2003.

BOADA, B.; TIRIRA, D. First record of partial albinism (leucism) in Carollia perspicillata (Phyllostomidae) in Ecuador. Chiroptera Neotropical, Brasília, v. 16, n. 2, p. 755-757, 2010.

BUYS, J.; HEIJLIGERS, H.; DORENBOSCH, M. First record of an albino long-eared bat Plecotus auritus in The Netherlands. Lutra, Almelo, v. 45, n. 1, p. 49-52, 2002.

CHARLES-DOMINIQUE, P.; BROSSET, A.; JOUART, S. Atlas des chauves-souris de Guyane. Vol. 49. Paris: Muséum National d'Histoire Naturelle Patrimoines Naturels, 2001. 172 p.

DEVKAR, R. V.; JAYARAMAN, S.; UPADHYAY, K.; PATEL, P. Albino microchiropteran, Rhinopoma microphyllum kinneri sighted in a bat colony inhabiting abandoned mines. Current Science, Bangalore, v. 100, n. 2, p. 165-166, 2011.

FALCÃO, F. C. First record of complete albinism in Carollia perspicillata (Chiroptera, Phyllostomidae). Chiroptera Neotropical, Brasília, v. 20, n. 1, p. 1234-1236, 2014.

FENG, L.; JIA, T.; SHU-YI, Z.; QI-CAI, C. A partial albino bat of Miniopterus magnater found in Anhui, China. Zoological Research, Yunnan, v. 28, n. 4, p. 443-445, 2007.

GAMBA-RIOS, M. A new case of albinism in the bat Micronycteris minuta (Chiroptera: Phyllostomidae) from Costa Rica. Ecotropica, Frankfurt, v. 16, n. 1, p. 59-61, 2010.

GARCÍA-MORALES, R.; GORDILLO-CHÁVEZ, E. J.; BELLOGUTIÉRREZ, J. Primer registro de albinismo en Glossophaga soricina (Phyllostomidae) en México. Chiroptera Neotropical, Brasília, v. 16, n. 2, p. 743-747, 2010.

GEIGER, D.; PACHECO, S. M. Registro de albinismo parcial em Nyctinomops laticaudatus (E. Geoffroy, 1805) (Chiroptera: Molossidae) no sul do Brasil. Chiroptera Neotropical, Brasília, v. 12, n. 1, p. 250-254, 2006.

HERNÁNDEZ-MIJANGOS, L. Registros de albinismo parcial en tres especies de murciélagos filostómidos (Chiroptera: Phyllostomidae) en Chiapas, México. Chiroptera Neotropical, Brasília, v. 15, n. 1, p. 441-445, 2009.

INMET - Instituto Nacional de Meteorologia-Ministério da Agricultura, Pecuária e Abastecimento. Disponível em: <http:// www.inmet.gov.br/portal>. Acesso em: 16 jan. 2017.

LEBLANC, F.; TAUPIN, F. Découverte d'une jeune grand murin (Myotis myotis) albinos en Corrèze (France): essai de synthèse sur les cas d'albinisme des Chiroptères en Europe. Le Rhinolophe, Genève, v. 17, p. 23-27, 2005.

MANTILLA-MELUK, H.; JIMÉNEZ-ORTEGA, A. M. First case of albinism in Uroderma bilobatum and its implications in the evolution of coat color patterns among Vampyressine bats. Investigación, Biodiversidad y Desarrollo, Quibdo, v. 30, p. 97 100, 2011.

MARIN-VASQUEZ, A.; ORTEGA-RINCÓN, M.; RAMÍREZCHAVES, H. E. Records of leucism in three species of Colombian bats: Carollia brevicauda, Artibeus jamaicensis and Lophostoma silvicolum (Phyllostomidae). Chiroptera Neotropical, Brasília, v. 16, n. 2, p. 706-709, 2010.

MILlER, J. D. All about albinism. Missouri Conservationist Magazine, Columbia, v. 66, n. 6, p. 4-7, 2005.

MIKICK, S. B.; BIANCONI, G. V.; MAIA, B. H.; TEIXEIRA, S. D. Attraction of the fruit-eating bat Carollia perspicillata to piper gaudichaudianum essential oil. Jounal of Chemical Ecology, Florida, v. 29, n. 10, p. 2379-2383, 2003.

MIRANDA, J. M. D.; KAKU-OLIVEIRA, N. Y.; MUNSTER, L. C. Primeiros dados de uma colonia reprodutiva de Myotis levis (I. Geoffroy, 1824) nos campos de Palmas, Paraná, Brasil (Verspertilionidae). Chiroptera Neotropical, Brasília, v. 16, n. 2, p. 762-768, 2012.

MURARIU, D.; CHISAMERA G. Partial albinism in noctule bat Nyctalus noctula (Schreiber, 1774) (Mammalia: Chiroptera) from Romania. Travaux du Muséum National d'Histoire Naturelle, Bucharest, v. 49, p. 353-357, 2006.

NAHARUDDIN, N. M.; SHAZALI, N.; LIBAR, R.; KARIM, N. F.; MOHD RIDWAN A. R.; ROSLAN, A.; ISHAM, M.; AZHAR M. I.; KHALIK, M. Z.; KHAN, F. A. Bats of Bako National Park and additional notes on the rare partial albinism in fawn roundleaf bat (Hipposideridae: Hipposideros cervinus. Borneo Journal of Resource Science and Technology, Malaysia, v. 5, n. 2, p. 44-52, 2015.

NATUURBERICHT. Albino vleermuis gevonden in Nederland. 2015. Disponível em: <http://www.natuurbericht. nl/?id=3897\&cat=zoogdieren $>$. Acesso em: 14 set. 2016.

NOAH. The National Organization for Albinism and Hypopigmentation. Disponível em: <http:/www.albinism.org/ publications/what_is_albinism.html>.Acesso em: 13 set. 2016.

OLIVEIRA H. F. M.; AGUIAR, L. M. S. A new case of complete albinism in a bat from Brazil. Chiroptera Neotropical, Brasília, v. 14, n. 2, p. 421-423, 2008. 
PAUTASSO, A. A.; BEVILAQCUA, M. S.; DE LA PEÑA, M. R.; RAMÍREZ, C. Observaciones sobre los murciélagos (Mammalia, Chiroptera) de la provincia de Santa Fe, Argentina. Natura Neotropicalis, Santa Fe, v. 40, n. 1-2, p. 95-101, 2009.

PRÉVOST, O.; DUCEPT, S.; GAILLEDRAT, M.; TRANCHANT, N. A propos d'un grand rhinolophe albinos dans la Vienne. L'Envol des Chiros, Bourges, v. 10, p. 10, 2011.

RAMASINDRAZANA, B.; WILKINSON, D. A.; BERAL, M.; DIETRICH, M. An albino molossid bat from the southwestern Indian Ocean region. Malagasy Nature, Madagascar, v. 8, p. 103104, 2014.

RAMÍREZ, N. N.; BOTTINELLI, O. R.; RUIZ, R. M.; BASTOS, R. S. Registro del primer caso de albinismo completo en Desmodus rotundus en Argentina. Revista Veterinaria, Botucatu, v. 21, n. 1, p. 63-65, 2010.

RENGIFO, E. M.; LINARES, V.; DÍAZ, F.; PANAIFO, J. First record of albinism in the black mastiff bat Molossus rufus E. Geoffroy, 1805. Chiroptera Neotropical, Brasília, v. 20, n. 2, p. 1288-1291, 2014.

ROMANO, M. C.; MONTANI, M. E.; CORDINI, M. C.; AUIL, S. First record of albinism in Tadarida brasiliensis (Chiroptera: Molossidae) in South America and new records of leucism in central Argentina. Chiroptera Neotropica, Brasília, v. 21, n. 1, p. 1312-1319, 2015.
SÁNCHES-HERNÁNDEZ, C.; ROMERO-ALMARAZ, M. L.; TABOADA-SALGADO, A.; ALMAZÁN-CATALÁN, J. A.; SCHNELL, G. D.; SÁNCHEZ-VÁZQUEZ, L. Five albino bats from Guerrero and Colima, Mexico. Chiroptera Neotropical, Brasília, v. 16, n. 1, p. 541-545, 2010.

SMIRNOV, D. G.; VEKHNIK, V. P.; KURMAEVA, N. M.; BAISHEV, F. Z. The Detection of partial albinism at three species of bats (Mammalia: Chiroptera) in European part of Russia. Open Journal of Animal Sciences, Penza, v. 4, p. 291-296, 2014.

SODRÉ, M. M.; UIEDA, W.; BALDIM, M. First record of albinism in the bat Eumops glaucinus (Molossidae) from southeastern Brazil. Chiroptera Neotropical, Brasília, v. 10, n. 1-2, p. 200-201, 2004.

SORIANO, P.; UTRERA, A.; SOSA, M. Dos registros de murciélagos albinos para Venezuela. Biollania, Llanos Occidentales, v. 9, p. 149-150, 1993.

TELlO, C.; STREICKER, D. G.; GOMEZ, J.; VELAZCO, P. M. New records of pigmentation disorders in molossid and phyllostomid (Chiroptera) bats from Peru. Mammalia, Paris, v. 78, n. 2, p. 191-197, 2014.

UIEDA, W. A review of complete albinism in bats with five new cases from Brazil. Acta Chiropterologica, Warszawa, v. 2, n. 1, p. 97-105, 2000.

UIEDA, W. Behavior of an albino vampire bat, Desmodus rotundus (E. Geoffroy) (Chiroptera, Phyllostomidae), in captivity. Revista Brasileira de Zoologia, Curitiba, v. 18, n. 2, p. 641-644, 2001. 